DOI: $10.52837 / 27382702-2021-34.1-84$

\title{
ON THE ISSUE OF THE PARTHIAN PAHLAVS' SOCIO-POLITICAL NATURE*
}

\author{
Arthur Melikyan
}

\begin{abstract}
The role of the high aristocracy, the so-called pahlavs, is undeniable in the history of the Parthian state. In the second half of III century BC the assistance of the pahlavs to the Arsacid dynasty considerably contributed to the establishment of the Dahae and organization of their own state in Parthia and Hyrcania. During the following centuries the rises and crises of the political life of the Parthian statehood and even its final decline in the first quarter of the III century was due to the attitude of the Parthian pahlavs towards the Arsacid dynasty. In spite of the key role of the pahlavs, the issues of their ethnic origin, social nature, their number and the relations with the royal power are still poorly studying in historical science. We hope that this article will bring its contribution in studying the history of the Parthian pahlavs.
\end{abstract}

Keywords: Arsacids, Parthia, Hyrcania, Dahae, Parni, Xanthii, Pissuri, Pahlav, Suren, Karen, synedrion, Strabo

\section{The setting of the issue}

According to the point of view accepted in the historical science the emergence of the Parthian pahlavs ${ }^{1}$ occured parallelly with the conquest of Hyrcania and Parthia by the tribe of Parni (Aparni) and was strongly influenced by this fact. After defeating Andragoras, the Seleucid ruler of Parthia, and the war with varying success against the Seleucid king Seleucus II Callinicus, Arsaces, the tribal leader of the Parni, usurped the power of the

\footnotetext{
* The article was submitted on May 13, 2021: The article was reviewed on May 18, 2021.

${ }^{1}$ For the Parthian (Dahae) high aristocracy we prefer to use the epithet pahlav applied by the medieval Armenian authors. It is the alternated form of the middle Persian word "parthian" "Parthava - ParHava" and changing its meaning, the best reflects the privileged position of the narrow elite of the Iranian aristocracy in the period of the Arsacids.
} 
king in accordance with the scheme of "the right of spear conquest" wellknown from the political history of the ancient world, and the elders of the Scythian community of the Parni occupied the social position of the Parthian high aristocracy ${ }^{2}$. All scholars more or less agree on this sequence of the events ${ }^{3}$.

In historical science, the Parthian Pahlavs were usually characterized by the epithets "Parthian nobles", "wealthy houses", "great clans", "great houses". Learning about the ethnic origin and social circle of Parthian state's high aristocracy constitutes a major problem for scholars. This is caused by the lack in sources of clear and precise information on Parthian society. The Greek and Latin authors writing about the state governed by the Arsacid dynasty were above all interested in politics: the conflicts with the Seleucids or with Rome; they paid attention to internal affairs only when these had an impact on the course of these conflicts. Most of these references are too general and circumstantial to base a credible reconstruction of the picture of the Parthian society on them ${ }^{4}$. Of course, they mostly focus on the aristocracy, and as a result the sources available on this group are suyciently - numerous that we can determine its political status, ideological positions, political role in the Parthian state and the nature of its relations with the rulers.

Studies of the Parthian aristocracy are few. The first scholar to had thoroughly discussed this social group was J. Wolski ${ }^{5}$. In terms of studying the issue, the works of Ed. Dąbrowa ${ }^{6}, \mathrm{~S}$. Hauser ${ }^{7}$ are also of great importance. Many questions have already received their answers. In this article we will try to answer questions about the ethnic origin and social circle of the highest

\footnotetext{
2 Wolski 1967, 1981, 1989, 1993; Wiesehöfer 2001: 139; Dąbrowa 2013: 54. This view was criticized by S. Hauser (Hauser 2005: 168-185; Hauser 2006: 295-319).

${ }^{3}$ For the period and circumstances of the emergence of the Arsacid state and issues of their elucidation in the ancient bibliography see Assar 2004: 69-93; Assar 2005: 29-63; Gaslain 2005a: 221-224; Gaslain 2005b: 9-30; Gaslain 2009: 27-39; Dąbrowa 2008: 25-31; Strootman 2018: 129-150; Overtoom 2020: 27-93.

${ }^{4}$ Dąbrowa 2013: 53.

${ }^{5}$ Wolski 1967, 1981, 1989, 1993.

6 Dąbrowa 2013: 53-62.

${ }^{7}$ Hauser 2005: 168-185; Hauser 2006: 295-319.
} 
aristocracy of the Parthian state, and will address the quantitative composition of the Parthian pahlavs elsewhere.

\section{The Genealogy of the Parthian Pahlavs}

The creation of their own state in Parthia and Hyrcania and the transition from the nomadic lifestyle to sedentary one radically transformed the social structure and political system of the Dahae tribal confederation. They successfully resembled the best elements of the Persian and Hellenistic administration and were able to resist the hostile environment. However, in the first period the rule of Arsacids was predominantly based on the support of Dahae, therefore the influence of the prior relations of the Dahae tribal society on the formation of the new political realities must have been significant. Strabo, testifying that the Dahae confederation consisted of three tribes, the Parni (Aparni), Xanthii and Pissuri ${ }^{8}$, states that the Parni tribe led by Arsaces, initiated the rebellious movement against the Macedonian rule. However, it does not follow from this that the Parni had a dominant or leading position in the Dahae confederation and the leadership of Arsaces equally or partially spread on the Xanthii and Pissuri. Just the opposite, it follows from the fact of the large area of distribution of the Dahae tribes in the Trans-Aral steppes and the habitation ${ }^{9}$ with the Saca-Scythian tribes that the Dahae confederation was founded on egalitarian principle. The initiation of the Parni to conquer Hyrcania and Parthia could have hardly changed it, as the Parni themselves were not capable of completing the conquest and resisting the hostile treatment of the neighbouring countries without assistance from the Pissuri and Xantii. On the other hand, for the Pissuri and Xantii participation in the conquest of Parthia became a mighty leverage for maintaining the old tribal equality in the new conditions. From this viewpoint the opinion of J. Wiesehöfer that the social elite of Arsacid state originated exceptionally from

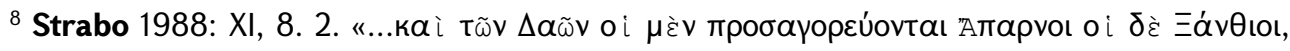

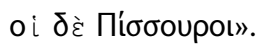

${ }_{9}^{9}$ Strabo 1988: XI, 9. 2. About the original habitat of the Dahae see Pyankov 1979: 195, n. 4.; Balakhvantsev 2018: 80-106.
} 
the Parni tribe, seems unacceptable ${ }^{10}$. It would be more reasonable to think that in the conditions of parity of the three tribes in the Dahae tribal confederation, the initiation of the struggle against the Macedonian rule elevated Arsaces from an ordinary tribal chief into the hegemon of the Dahae chief tribes (primus inter pares) but without giving real power over two fraternal tribal chiefs, and the latters formed Arsaces' entourage.

The rather slow process of the establishment of the royal authority during the reign of Arsaces I (c. 247-211 BC) must be explained by the inertia of the old tribal lifestyle ${ }^{11}$. This is apparent not only from the slow and cautious change of Arsaces l's insignia and titles ${ }^{12}$, but also from the saga in $M$. Khorenatsi's "History of Armenia"13 about the origins of the Parthian pahlavs, which is a distant echo of the resistance of the Dahae tribal council on the rise of the Arsacids.

In the first half of 230s BC while making his second attempt to gain a foothold in the territory of Parthia, Arsaces I had to resist the anti-Dahae alliance of Seleucus II (c. 246-225 BC) and Diodotus I (c. 255-235 BC) which was possible only in the case of concentration of military potential and finding recognition in the role of all-union military leader. It is natural that this could have been at the expense of the rights of the tribal councils of the Xantii and Pissuri. As it is seen from the taking the title of "Karen» "Krny"14 by Arsaces I, motivated by the need to gain a foothold in the newly conquered territory, the Dahae elders agreed to this partial concession ${ }^{15}$. It is noteworthy that even after his establishment in Parthia and the official coronation in Asaak ${ }^{16}$,

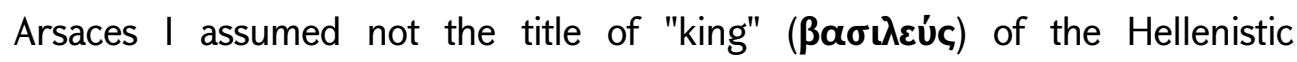
monarchs, but the title of "autocrat" (auтократор), still emphasizing the

\footnotetext{
${ }^{10}$ Wiesehöfer 2001: 139.

${ }^{11}$ Sellwood 1980: Type 1-4. For the numismatic iconography and the changes of titles of Arsac I see Assar 2005: 29-35; Melikyan 2012: 33-69: Koshelenko, Gaibov 2013: 327-347.

12 Melikyan 2012: 69-70:

${ }^{13}$ Movses Khorenatsi 1981: II, 28.

${ }^{14}$ Sellwood 1980: Type 3.

${ }^{15}$ Melikyan 2012: 62-64:

${ }^{16}$ Isidoros 2013: 11.
} 
military and heavy-handed nature of his rule ${ }^{17}$. Although this fact was interpreted in various ways ${ }^{18}$, we believe that Arsaces I's abdication of the royal title was conditioned not by relinquishing monarchic ambitions, but by the resistance of the Dahae elders. It is possible that by allegedly resigning from the monarchy Arsaces I paid a tribute to the old tribal traditions of the Dahae and the self-esteem of the Dahae elders ${ }^{19}$ or provided an opportunity to the Dahae elders to live under the illusion of the old tribal (chieftaincy) equality.

In a brief narrative of Arsaces l's state-building, Justinus does not mention his social transformations. The author only mentions that "Arsaces not only reached royal power, but also organized his kingdom ..."20. However, the author's phrase "organized his kingdom" itself implies social initiatives, too, first of all, the definition of the place and role of the Dahae society and its nobility in the newly established state and its legal relationship with the royal authority. The fact that Arsaces I adopted the titles of the Hellenistic courts shows that palatial ranks of hierarchy were introduced in the earliest period of the Arsacid state ${ }^{21}$.

Unfortunately, there are no official sources that reflect the hierarchical system of the early Arsacid period, like the ones about the early Sassanid period. For this reason, the questions concerning the hierarchical system of the Arsacids and the place of the pahlavs within it were often treated based on the assumption that the Sassanids inherited the four tier hierarchy ranking of the nobility from the Arsacids and therefore the pattern of the period of the early Sassanids (subject kings (šahrdārān) members of the royal house (wāspuhragān), representatives of authoritative clans (wuzurgān) official (azādān) class) objectively reflects the administrative-political image existed during the late Arsacid period ${ }^{22}$. This opinion is yet to be supported by

\footnotetext{
17 See Bikerman 1985: 12; Olbrycht 2011: 230, footn. 4.

${ }^{18}$ Masson, Romodin 1964: 102-103; Koshelenko 1968: 65; Koshelenko 1971: 212; Strootman 2018: 129-150.

${ }^{19}$ Melikyan 2012: 63-64:

20 Justinus 1886: XLI, 5.5 .

${ }^{21}$ Wiesehöfer 2001: 139.

22 Frye 1983: 316; Lukonin 1987: 120; Khurshudyan 2015: 7-20.
} 
evidence $^{23}$. However, even though we accept it with substantial reservations, it must be noted that his methodology does not allow to specify nor the initial social position of the Parthian pahlavs, neither their number. One can not ignore the circumstance that in the c. 500 year between the second half of the III century BC and the first quarter of the III century AD external and internal transformations of the Arsacids (evolving from a regional local state into an empire, long-lasting wars with the neighbours, permanent fights for the throne, federalism of the state, etc.) would have influenced the radical changes in that hierarchical system, as well. Therefore, the hierarchical systems, the number of the Parthian pahlavs included in it and the socialpolitical position that existed in the first and last period of the Arsacid rule could not have been identical. Nevertheless, the investigation of Shapur I's trilingual inscription of Kaaba-i Zardusht (ŠKZ) ${ }^{24}$ allows us to suppose that the hierarchical systems of the early Arhsacids and the early Sassanids had principal commonalities. In ŠKZ the court lists of Papak, Ardashir I (224-241) and Shapur I (241-272) are compiled on the principle of honoral relations ${ }^{25}$. That is, the place of a courtier was determined by his nobility and then by its office $^{26}$. From this one can conclude that the early Parthian royal hierarchy was created on a similar principle. In the early period of the Arsacid state, when the monarchy was still in its infancy, the king was regarded as the "first among equals" by the inertia of the old tribal coexistence, the Dahae elders must have fixed their positions and become recognizable not only in war, but also in peace ${ }^{27}$. Unfortunately, except the mythical saga by M. Khorenatsi, there is no other information about this process. Similarly, it is unknown what Iranian term defined the social position of the Parthian pahlavs. K. Toumanoff, A. Mousheghyan and others attributing an Arsacid ancestry to the Parthian pahlavs, assume that in the Parthian royal hierarchy they were the social

\footnotetext{
${ }^{23}$ Wiesehöfer 2001: 139.

${ }^{24}$ Sprengling 1953; Honigmann, Maricq 1953.

25 Daryaee 2007: 65-72.

${ }^{26}$ Khuršudyan 1992: 69-74.

${ }^{27}$ Wiesehöfer 2001: 139.
} 
stratum of "wāspuhragān $»^{28}$. Moreover, from the sociological and legal point of view comparing "seven great houses of the vāspuhrān" with the "Caucasian lesser, non-dynastic, nobility» Toumanoff significantly maintained that the "political and social importance of ... [these Parthian families] was commensurable with that of the greatest of the Caucasian [dynastic] Princes"29. However, as we will see below, the hypothesis of the Arsacid origin of the pahlavs is the result of source study misconception. In fact, their position in the Parthian society should have been equivalent to the social class described as "wuzurgān" ("nobleman") in the Sassanid lithographs with the difference that in the Sassanid court "wuzurgān" was the third, and in the Arsacid state, as it had not yet evolved into an empire and become federal, it should have formed the sub-peak of the social hierarchy.

\section{The social-political nature of the Parthian pahlavs}

The written sources solidarily confirm the tribal origins of the Parthian high aristocracy. Thus, there is much evidence of the Parthian nobility in the writings of Tacitus, Plutarch, and Dion Cassius. However, these Roman authors mention only the representatives of the two clans, Suren and Karen, not by a person (nomen), but by a lineage name (cognomen) ${ }^{30}$. This distinction speaks for itself about the special position of the Suren and Karen clans in the Arsacid state.

Seneca calls the elite of the Parthian tribal elders "megistanes" (Greek $\mu \varepsilon ү\lrcorner \sigma \tau \tilde{\alpha} \nu \varepsilon \varsigma)$, describing them as the heads of the noblest clans ${ }^{31}$. Suetonius describes the closest circle of the Arsacid kings with the same epithet ${ }^{32}$. Justinus (Pompeius Trogus) calls the high aristocracy of the Arsacid state

\footnotetext{
28 Toumanoff 1963: 262; Frye 1983: 316; Moushegyan 2007: 246-299:

29 Toumanoff 1963: 262.

30 Tacitus 1886: VI, VI. 42; XII, 12-13; Plutarch 1932: Crassus 21; 23; 24; 28-33; Dio Cass. 1955: XLVIII, 16.1; XLVIII, 20.4; XLVIII, 21.1; XLVIII, 26.1-3;

${ }^{31}$ Seneca 1996: 140-147.

32 Suetonius 1914: IV. 5: Josephus 1937: XI, 3.2.
} 
standing close to the king "rank of councillors" (ordo probulorum) ${ }^{33}$. In Agatangełos's "Armenian History", Karen and Anak, representatives of the high Parthian aristocracy, are characterized by the expressions "a chief patriarch of the Parthian state" 34 and "high-ranking official, ancestorstrategus" ${ }^{35}$, which makes apparent their patriarchal (tribal) nature. For M. Khorenatsi, too, the notion pahlav means socio-political status and concerns a narrow group of esteemed "Parthian lords" standing higher from other rulers and subject kings ${ }^{36}$. M. Khorenatsi repeatedly uses the phrase "Parthian and Pahlavik nations" ${ }^{\prime 37}$, which also has an element of social differentiation, such as existing in the contrast between "senior minister" and "junior minister" used in the Armenian reality. The author describes the social position of the

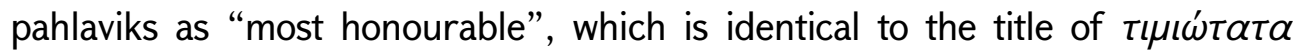
used by Greek authors ${ }^{38}$. One can conclude from it that M. Khorenatsi's use of the term pahlav (in Tabari's History pahlavs are called "fahlav" ${ }^{39}$ ) within its social meaning is close if not equal to the Herodotus's term "first Persians"40 about the earliest Achaemenid period and Xenophon's term "honourable Armenians" 41 about Yervandian (Haikazian) Armenia. Both cases concern the narrow circle of the social elite standing after the king, which had a subethnic, tribal origin. Therefore, we can state with more or less confidence that the term pahlav/fahlav used in the sources had an eponym meaning in intersocietal scales.

\footnotetext{
33 Justinus 1886: XLI, 2. 2. "Closest to the kings in rank are the councillors [ordo probulorum], and from among them they choose their commanders in war [duces], as well as their leading politicians in peace [rectores]》:

${ }^{34}$ Agatangełos 1983: 25

${ }^{35}$ Chunakova 1980: 204.

${ }^{36}$ Olshausen 1877: 18-19.

${ }^{37}$ Movses Khorenatsi 1981: II, 71: II, 72.

38 Probably Tabari's use of the term "bihkanid" about the pahlavs must have the same meaning.

(Tabary 1987: 77):

39 Tabary 1987: 77 (683).

${ }^{40}$ Herodotus 1914: III.68-70; III. 77: Briant 2002: 28-29.

${ }^{41}$ Xenophon 1998: III, 1:
} 
The honorary title of "relatives» ( $\sigma u \gamma \gamma \varepsilon v o l)^{42}$ given by Strabo is more telling for the revelation of the social nature of the members of the upper strata of the Arsacid hierarchy.

Literal perception of the phrase "relatives (of the king)", as well as honouring each other with the word "brother"43 in the context of palatial code of conduct and in the official correspondence leaned some medieval authors and even many modern scholars to the opinion that the Parthian pahlavs were of Arsacid origin ${ }^{44}$. But in reality it was a widespread title in the Achaemenid and Hellenistic courts bestowed to the persons very close to him and brought up together ${ }^{45}$. Narrowing the social circle of the "relatives" it comes down to a close circle of the aristocracy "equal in origin". In the Arsacid state it could be identical only to the class of the tribal elders of the Dahae.

In the Seleucid court the title of "relative (of the king)" had a personal nature ${ }^{46}$, while Plutarch's mention ${ }^{47}$ of the "clannish" right of the patriarchs of the Suren clan to crown the Parthian kings shows that the honourary position of the pahlavs in the court of the Arsacids was hereditary. Unfortunately, the Classical sources are silent on the similar "clannish" rights of the other Parthian pahlavs. One can assume that having such functions they were practically deprived of the opportunity to interfere in the state life by right and became involved in the military and administrative affairs only by the order of

\footnotetext{
42 Strabo 1988: XI, 9. 3.

43 Bikerman 1985: 43, no. 135.

${ }^{44}$ See Buzand P'avstos 1987: 4, 33; Khorenatsi Movses 1981: II, 28: Warner, Warner 2013: 185.

A. Mušeğyan believes that the pahlavs were of Arsacid origin and tries to represent them as the social class of "wāspuhragān." The author draws parallels with the similar phenomenon witnessed in the Armenian court from the point of view of Khorenatsi's story about distirbuting domains to the "Pahlaviks." (Mušeğyan 2007: 246-255, 291-299):

45 Xenophon 1914: I, VI. 1; I, VI. 10; Josephus 1937: XI, 3. 2; Bikerman 1985: 4-43; Strootman 2013: 38-53.

${ }^{46}$ Bikerman 1985: 41-42.

47 Plutarch 1932: Crassus. 21. Moreover, he enjoyed the ancient and hereditary privilege of being first to set the crown upon the head of the Parthian king", Tacitus 1886: VI, VI. 42; Lukonin 1983: 704.
} 
the $\mathrm{king}^{48}$. It was in the interest of the Arsacids to strengthen the royal power at the expense of the elders, although the fact is that with this method the Arsacids were not able to undermine the public authority of the pahlavs based on the "right of origin". With the territorial expansion of the Parthian state the Parthian pahlavs accumulated great economic power, partly due to war spoils and in part to their participation in international trade. Thanks to the patriarchal power and large material resources, they had spacious domains, a vast subordinate population, and a large number of private troops ${ }^{49}$.

According to Strabo, in Arsacid court "relatives (of the king)" formed a separate council which in fact was similar to Heredotus's "royal council" of "first Persians". It is known that the "royal court" of the Achaemenids did not have institutional existence based on special and inviolable rules issued by the king. Its sessions and discussions were exceptionally dependent on the will of the king, and the membership in the council was not imposed on the king, but the latter choosed its advisers from the aristocracy ${ }^{50}$. In the case of the Arsacid "royal council" the relations seem to be different. Strabo referring Posidonius, reports: "Council of the Parthians, ... consists of two groups, one that of kinsmen, and the other that of wise men and Magi, from both of which groups the kings were appointed ${ }^{51}$. This makes apparent that in the Arsacid state life the position of "relatives (of the king)" was incomparably stable and their "council" albeit adjacent to the king, was institutional. Otherwise, Strabo referring to philosopher, geographer and historian Posidonius of Apameia (around 135-51 BC) would not have spoken about the "council of the relatives" as a fact existing in his times. Probably, the longevity of the "constitutional"

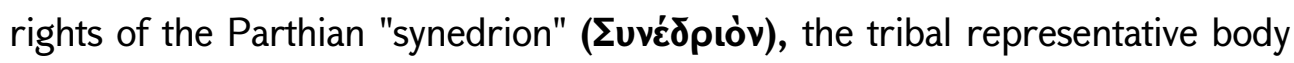
of the Dahae, was due, on the one hand, to the viability of the old tribal patriarchal traditions in the Dahae society and on the other hand, to the

\footnotetext{
48 Justinus 1886: XLI, 2. 2.

49 Farrokh 2007: 157; Dąbrowa 2013: 55-56.

50 Briant 2002: 128-129.

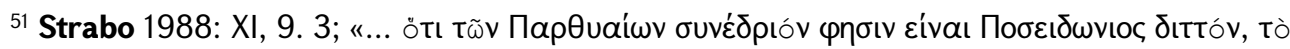

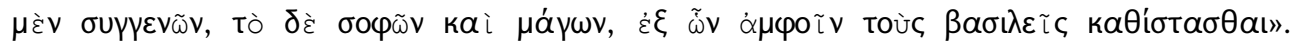
Josephus 1965: XVIII, 44.
} 
intention of the Arsacids to acquire political support of the highborn elders in the newly established state. In any case, the preservation of the right of the

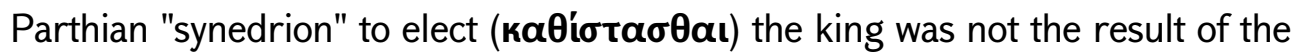
Arsacid tradition, but the inability to overcome the order of the old tribal past. From the abovementioned report of Strabo follows that, like in other societies transited from tribal lifestyle to early state societies, in the Dahae society, the council of elders, as the highest representative body of the people, was the supreme bearer of the state authority. Apparently, the Dahae elders clung to that right. Moreover, the right of the elders to elect a king automatically makes clear the reverse right to dethrone an already elected king ${ }^{52}$. Based on numerous source and numismatic facts, G. Koshelenko, G. Assar and others conclude that the first victim of the above-mentioned right of the Dahae elders was Arsaces I's son and successor, Arsaces II ${ }^{53}$. Justinus, speaking of the brutal rule of Mithridates III (57-54 BC), testifies that he "... was expelled from the country by the council of the Parthian elders (Senatus Parthorum) for his cruelty" ${ }^{\prime 54}$. There is plenty of evidence in the sources about the king-making and anti-royal activity of the Parthian elders. However, we believe that the above-mentioned examples are enough to come to an unequivocal conclusion: if the Parthian synedrion continued to be the supreme bearer of the state authority in the period of incomparably high level of maturity of the Arsacid state, then its role should have been greater in the earliest period of the formation of the state ${ }^{55}$. In fact, it would be right to consider the political decision on "willingly accepting the kingdom of Ardashir, son of Sasan" instead of the Arsacids, made by the Parthian Pahlavs at the beginning of 220s, within the bounds of the above-mentioned competencies of the Parthian synedrion, which became the reason for the fall of the c. 500 year old state of the Arsacids.

52 See. Dąbrowa 2010: 125.

${ }^{53}$ Koshelenko 1976: 33-34. Assar 2004: 81.

${ }^{54}$ Justinus 1886: LXII, IV. 1, «Mithrdates rex Parthorum... propter crudelitate a senatu Parthico regni pellitur...»: see. Tacitus 1886: II, 2.1.

${ }^{55}$ Melikyan 2012: 69: 


\section{BIBLIOGRAPHY}

Agatangełos 1983: Hayots patmut'yun (History of Armenia), aškharhabar t'argmanut'yunə ev c'anot'agrut'yunə Aram Ter-Ghevondyani, Yerevan (in Armenian).

Assar G.F. 2004: Genealogy and Coinage of the Early Parthian Rulers. I, Parthica, № 6, 69-93.

Assar G.F. 2005: Genealogy and Coinage of the Early Parthian Rulers. II. A Revised Stemma, Parthica, № 7, 29-63.

Balakhvantsev A. 2018: Političeskaya istoriya Ranney Parfii (The political history of Early Parthia), Moskva (In Russian).

Bikerman E. 1985: Gosudarstvo Selevkidov (The Seleucid State), Moskva (In Russian).

Briant P. 2002: From Cyrus to Alexander: A History of the Persian Empire, Winona Lake, Indiana: Eisenbrauns.

Chunakova O. 1980: Otgoloski «Deyaniy Ardašira Papakana» v drevnearmyanskoy literature, Patma-banasirakan handes, № 4 (91), 196-207 (in Russian).

Dąbrowa Ed. 2008: The Political Propaganda of the First Arsacids and it's Targets (From Arsaces I to Mithrdates II), Parthica № 10, 25-31.

Dąbrowa Ed. 2010: The Parthian Kingship, in Concepts of Kingship in Antiquity. Proceedings of the European Science Foundation Exploratory Workshop (held in Padova, November $28^{\text {th }}-$ December $\left.1^{\text {st }}, 2007\right)$, ed. by Giovanni B. Lanfranchi \& Robert Rollinger, Padova,123-134.

Dąbrowa Ed. 2013: The Parthian Aristocracy: its Social Position and Political Activity, Parthica 15, 53-60.

Daryaee T. 2007: The Middle Persian Text Sur i Saxwan and the Late Sasanian Court // Des Indo-Grecs aux Sassanides: Donnees pour l'historie et la geographie historique. Res Orientales, № 17, 65-72.

Dio Cassius. 1955: Dio's Roman History, with an English translation by Earnest Cary, on the basis of the Version of Herbert Baldwin Foster, in Nine Volumes, Vol. IX, London-Cambridge/Massachusetts.

Farrokh K. 2007: Shadows in the Desert: Ancient Persia at War, New York.

Frye R.N. 1983: The History of Ancient Iran, München.

Gaslain J. 2005a: Arsaces I, the First Arsacid King? Some Remarks on the Nature of Early Parthian Power, in Central Asia from the Achaemenids to the Timurids. Archaeology, History, Ethnology, Culture. Materials of an International Scientic 
Conference dedicated to the Centenary of A. M. Belentitsky, St. Petersburg, November 2-5, 2004, St. Petersburg, 221-224.

Gaslain J. 2005b: Le bachlik d'Arsace ler ou la representation du nomade-roi, in Bulletin of Parthian and Mixed Oriental Studies, № I, 9-30.

Gaslain J. 2009: A propos d' Arsace ler, Electrum, № 15, 27-39.

Hauser S. R. 2005: Die ewigen Nomaden? Bemerkungen zu Herkunft, Militär, Staats aufbau und nomadischen Traditionen der Arsakiden, in B. Meißner, O. Schmitt, M. Sommer (hrsg. von), Krieg - Gesellschaft - Institutionen. Beiträge zu einer vergleichenden Kriegsgeschichte, Berlin, 163-208.

Hauser S. R. 2006: Was there no Paid Standing Army? A Fresh Look on Military and Political Institutions in the Arsacid Empire, in M. Mode, J. Tubach (eds.), Arms and Armour as Indicators of Cultural Transfer, Wiesbaden, 295-319.

Herodotus 1914: The History of Herodotus, Volume I-II, Translated by G. C. Macaulay, London,

Honigmann E., Maricq A. 1953: Recherches sur les Res Gestae divi Saporis, Bruxelles.

Isidoros 2013: Parthian Stations by Isidore of Charax. An Account of the overland trade Route between the Levant and India in the first Century B. C., The Greek Text, with a Translation and Commentary by W.H. Schoff, Chicago.

Josephus 1937: Jewish Antiquities, Vol. IV (Books 9-11): Translated by Ralph Marcus (Loeb Classical Library).

Josephus 1965: Jewish Antiquities, Vol. VIII (Books 17-18), Translated by Louis H. Feldman (Loeb Classical Library).

Justinus M. 1886: Epitoma Historiarum Philippicarum Pompei Trogi, Ed. F. Ruehl, Lipsiae.

Movses Khorenatsi 1981: Hayots patmut'yun (History of Armenia), ashkharhabar t'argmanut'yunə ev meknabanut'yunnerə S. Malkhasyani, Yerevan (in Armenian).

Khurshudyan Ed. 1992: Iranskaya voenno-administrativnaya terminologiya i problema četyrekhčlennogo deleniya Sasanidskogo Irana (Iranian military-administrative terminology and the problem of the four-term division of Sassanian Iran), Patmabanasirakan hands, № 1, 69-74 (in Russian).

Khurshudyan Ed. 2015: Gosudarstvenniye instituti Parfyanskogo i Sasanidskogo Irana (State institutions of Parthian and Sassanian Iran), Almaty (in Russ.).

Koshelenko G. A. 1968: Nekotoriye woprosi istorii ranney Parfii (Some questions of the history of early Parthia), Vestnik drevney istorii, №1, 53-71 (in Russian). 
Koshelenko G. A. 1971: Tsarskaya vlast' i eyo obosnovaniye $v$ ranney Parfii (Royal power 'and its rationale in early Parthia), sm.- ? Istoriya iranskogo gosudarstva i kul'turi: k 2500-letiyu Iranskogo gosudarstva, pod red. B. G. Gafurova i dr., Moskva, 212-216 (in Russian).

Koshelenko G. A. 1976: Geneologiya pervykh Aršakidov (eščyo raz o nisiyskom ostrakone N 1760) (Genealogy of the first Arshakids (once again about the Nisian sharp N 1760)), sm.-? Istoriya i kul'tura narodov Sredney Azii (drevnost' i srednie veka), pod red. V. G. Gafurova i V. A. Litvinskiy - ?, Moskva, 31-37 (in Russian).

Koshelenko G. A., Gaibov V. A. 2013: Aršak I i ego monetniy čekan, Monumentum Gregorianum, Sbornik naučnykh statey pamyati Grigoriya Maksimoviča BongardLevina, otv. red. A. I. Ivančik, Moskva, 327-347 (in Russian).

Lukonin V. G. 1983: Political, Social and Administrative Institutions, In: Yarshater Ehsan (ed.), Cambridge History of Iran, 3.2, London, Cambridge, 681-747.

Lukonin V. G. 1987: Drevniy i rannesrednevekoviy Iran (Očerki istorii kul'tury) (Ancient and early medieval Iran (Essays on the history of culture),), Moskva (in Russian).

Masson V. M., Romodin V. A. 1964: Istoriya Afganistana (History of Afghanistan), t. 1, Moskva (in Russ.).

Melikyan A. 2012: Ankakhut'yan gağap'ari patkeragrut'yunə Aršak Arajini dramneri vra (The Iconography of the Idea of Indenpendece on the Currency of Arsaces I), In: Mijazgayin gitažoğovi nyut'er, Vanadzor, 33-78 (in Armenian).

Musheghyan A. 2007: Movses Khorenatsu darə (The Period of Movses Khorenatsi), Yerevan (In Armenian).

Olbrycht M. J., 2011: Titulatura Pierwszych Arshakido'w i Jej Polityczno-Religijne Knotacje. In Gniezno European Studies Monograph Series, Vol. IV. The World of Antiquity, its Polish Researchers and the Cult of the Ruler, pod redakcją Leszka Mrozewicza i Katarzyny Balbuzy, Poznań, 2011, p. 230, ftn. 4, 229-241.

Olshausen J. 1877: Parthava und Pahlav. Mada und Mah, Berlin.

Overtoom L. N. 2020: Reign of Arrows, The Rise of the Parthian Empire in the Hellenistic Middle East, New York.

P'avstos Buzand 1987: Hayots patmut'yun (History of Armenia), aškharhabar t'argmanut'yunə ev c'anot'agrut'yunə S. Malkhasyantsi, Yerevan (in Armenian).

Plutarch 1932: Lives, with an English Translation by Bernadotte Perrin, in Ten Volumes, Vol. I, III, Pericles and Fabius Maximus, Nicias and Crassus, the Loeb Classical Library, London-New York.

Pyankov V. 1979: K voprosu o putiyakh proniknoveniya iranoyazyčnykh plemen v Perednyuyu Aziyu (To the question of the ways of penetration of the Iranian- 
speaking tribes into the Middle East,), Predneaziatskiy sbornik, III, Istoriya i filologiya stran Drevnego Vostoka, pod red. M. A. Dandamaeva, V. A. Livšitsa, Moskva, 193-207 (in Russian).

Sellwood D. 1980: An Introduction to the Coinage of Parthia, $2^{\text {nd }}$ edit., London.

Seneca L. 1996: Epistles 1-65, With an English Translation by Richard M. Gummere, Harvard University Press, Cambridge - London.

Sprengling M. 1953: Third Century Iran: Sapor and Kartir, Chicago.

Strabo 1988: The Geography of Strabo, Vol. V (books X-XII), with an English translation by H.L. Jones. Cambridge/Mass., London,.

Strootman R. 2013: Dynastic Courts of the Hellenistic Empires, in H. Beck (ed.), A Companion to Ancient Greek Government, Malden-Oxford, 38-53.

Strootman R. 2018: The Coming of the Parthians: Crisis and resilience in Seleukid Iran in the reign of Seleukos II, in: K. Erickson ed., The Seleukid Empire, 281-222 BC: War Within the Family, Swansea, 129-150.

Suetonius 1914: Lives of the Caesars, Volume I: Julius. Augustus. Tiberius. Gaius. Caligula, Translated by J. C. Rolfe. Introduction by K. R. Bradley, Cambridge (Loeb Classical Library 31).

Tabary 1987: The History of al-Tabari (Ta' rikh al-rusul wa' I-muluk), Volume IV, The Ancient Kingdoms, translated and Annotated by Moshe Perlmann, New York.

Tacitus P. C. 1886: P. Cornelii Taciti Annalium ab excessu divi Augusti libri / The Annal's of Tacitus, Edited with Introduction and Notes by Henry Furneaux, M.A., vol. 1 (Books XI-XVI), Oxford.

Tacitus P. C. 1891: P. Cornelii Taciti Annalium ab excessu divi Augusti libri / The Annal's of Tacitus, Edited with Introduction and Notes by Henry Furneaux, M.A., vol. 2 (Books XI-XVI).

Toumanoff C. 1963: Studies in Christian Caucasian History, Washington, D.C.

Warner A.G., Warner Ed. 2013: The Shahnama of Firdausi, Volume 7. - ByArthur George Warner, Edmond Warner, London, 2013.

Wiesehöfer J. 2001: Ancient Persia from 550 BC to 650 AD, Translated by Azizeh Azodi, London-New York.

Wolski J. 1967: L'aristocratie parthe et les commencements du féodalisme en Iran, Iranica Antiqua 7, 133-144.

Wolski J. 1975: Le classi inferiori della popolazione nel regno dei Parti, in I. Biez ' uńska-Małowist - (a cura di), Storia sociale ed economica dell'età classica negli studi polacchi contemporanei, Milano, 55-61. 
Wolski J. 1981: L'aristocratie foncière et l'organistation de l'armée parthe, Klio, 63, 105-112.

Wolski J. 1983: Les relations de Justin et de Plutarque sur les esclaves et la population dépendante dans l'Empire parthe, Iranica Antiqua 18, 145-157.

Wolski J. 1989: Die gesellschaftliche und politische Stellung der großen parthischen Familien, Tyche, 4, 221-227.

Wolski J. 1993: L'Empire des Arsacides (Acta Iranica, 32, 3e série, Textes et Mémoires, 18), Lovanii.

Xenophon 1998: Anabasis, Translated by Carleton L. Brownson, Harvard University Press, Loeb Classical Library.

Xenophon 1914: Cyropaedia, Volume I, with an English Translation by Walter Miller, in two volumes, London-New York.

Arthur Melikyan

Vanadzor State University, Republic of Armenia arthurmelikyan@rambler.ru

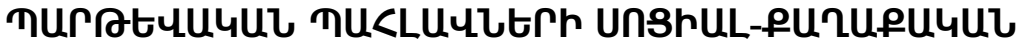

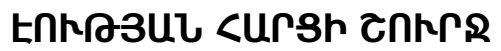

\section{Unpnıр Utiцpјшu}

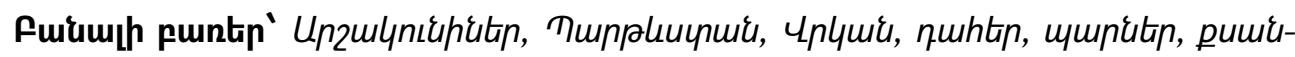

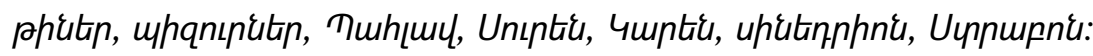

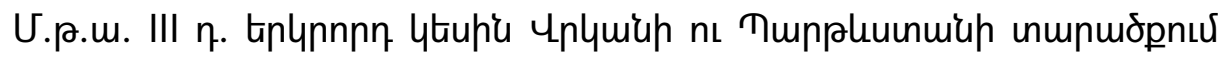

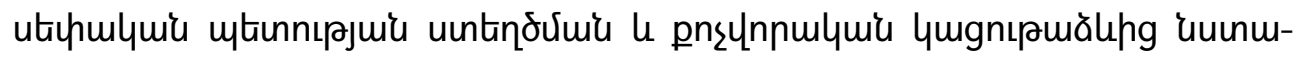

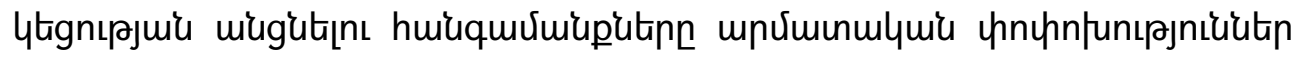

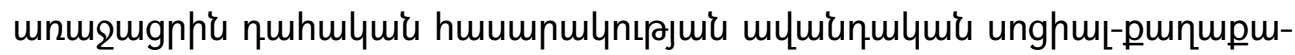

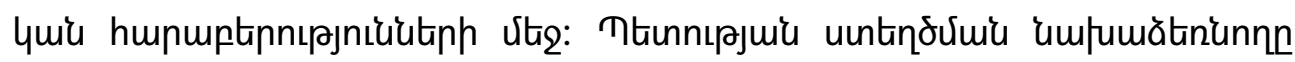

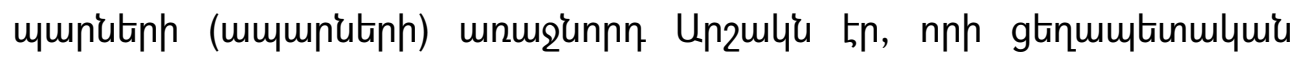

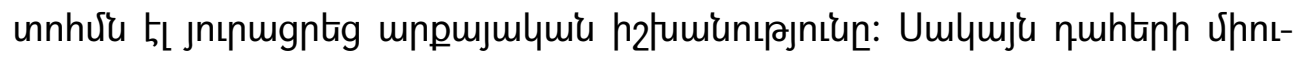

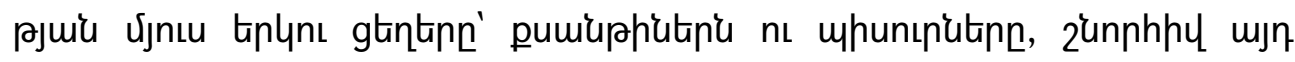

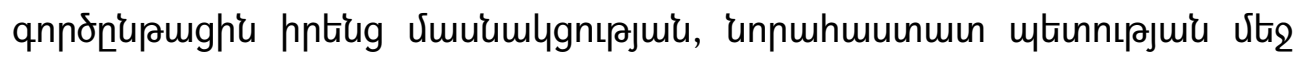

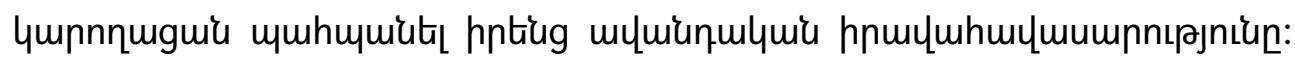

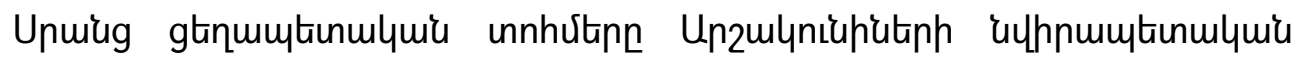




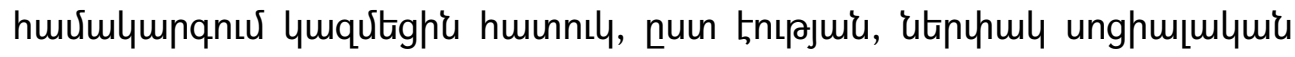

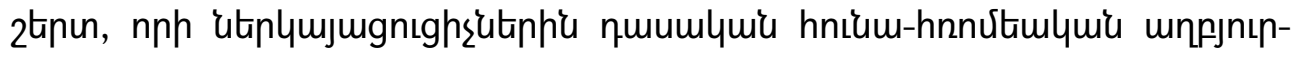

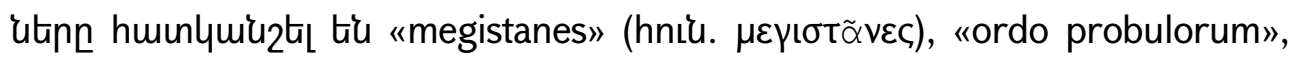

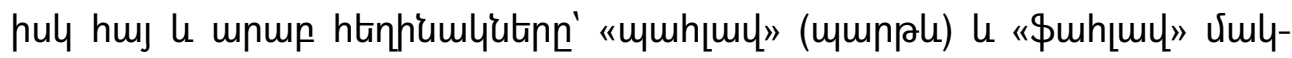

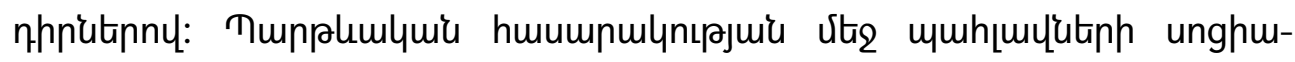

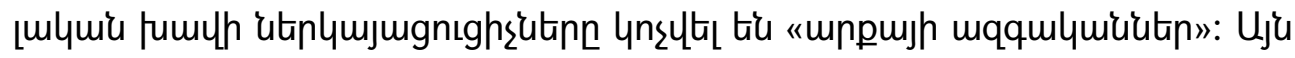

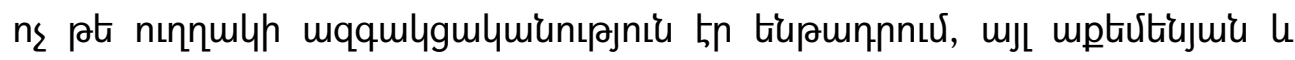

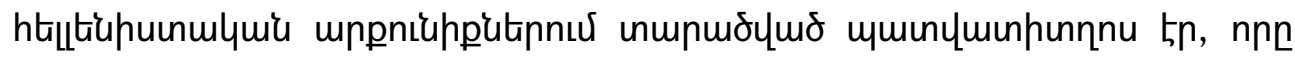

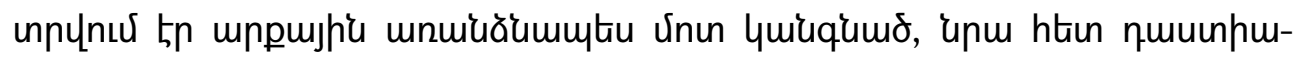

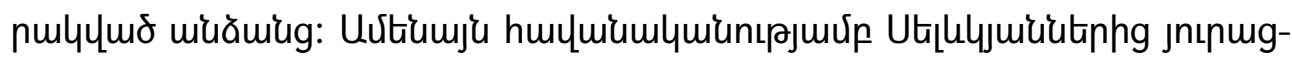

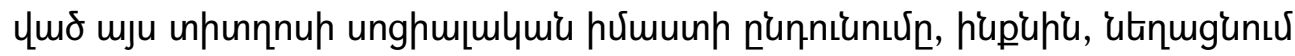

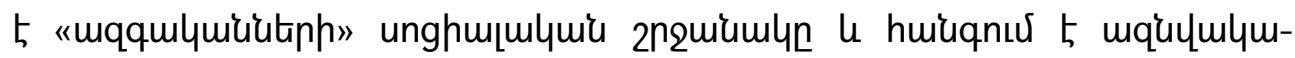

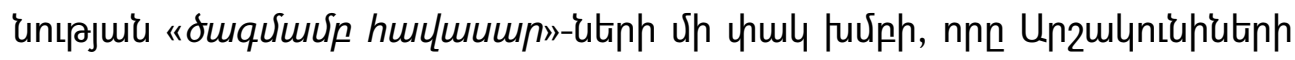

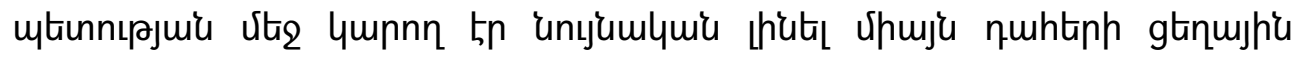
mymquiuns fumuhis:

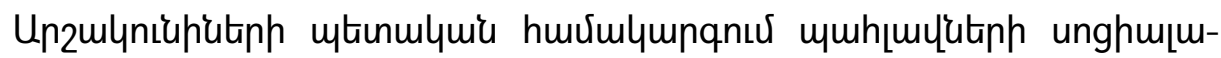

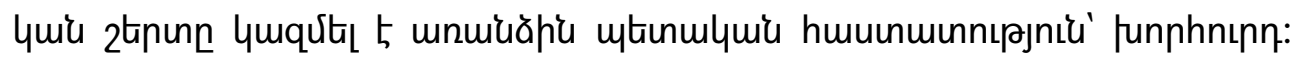

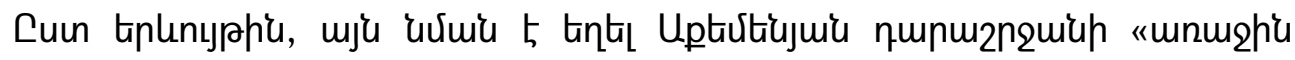

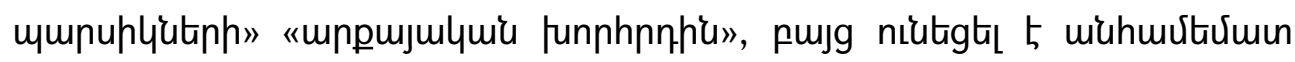

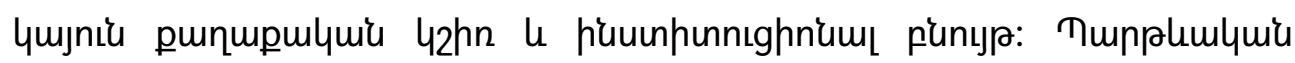

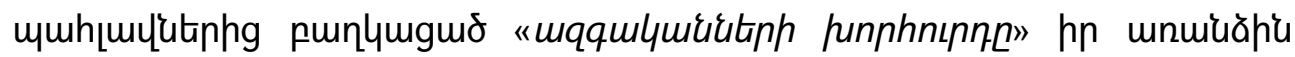

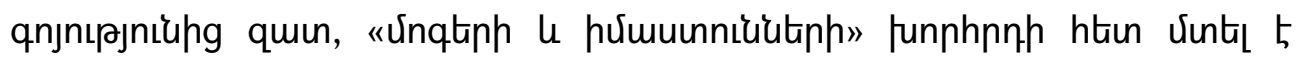

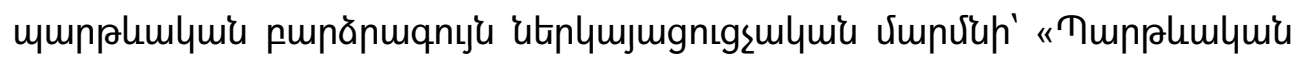

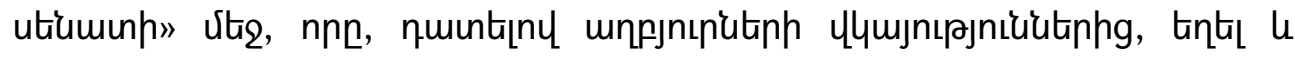

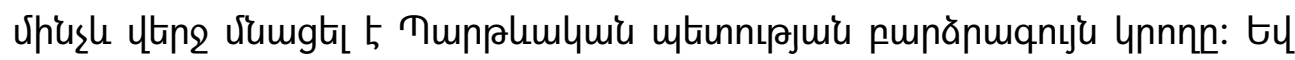

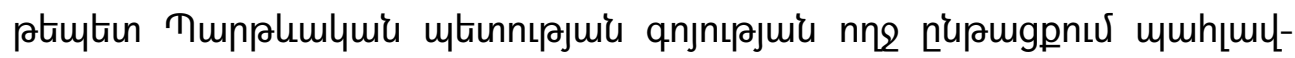

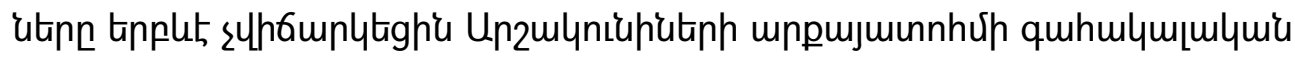

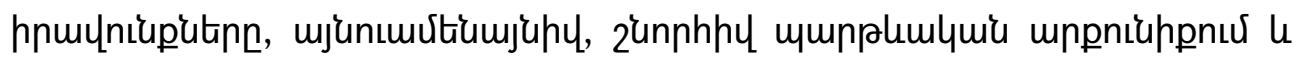

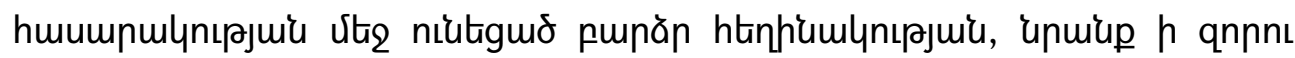

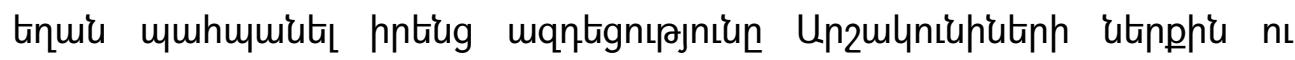

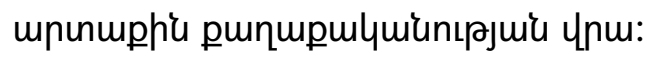

